Research Paper

\title{
Biomineralization processes of calcite induced by bacteria isolated from marine sediments
}

\author{
Shiping Wei, Hongpeng Cui, Zhenglong Jiang, Hao Liu, Hao He, Nianqiao Fang \\ School of Marine Sciences, China University of Geosciences, Beijing, China.
}

Submitted: June 24, 2014; Approved: November 16, 2014.

\begin{abstract}
Biomineralization is a known natural phenomenon associated with a wide range of bacterial species. Bacterial-induced calcium carbonate precipitation by marine isolates was investigated in this study. Three genera of ureolytic bacteria, Sporosarcina sp., Bacillus sp. and Brevundimonas sp. were observed to precipitate calcium carbonate minerals. Of these species, Sporosarcina $s p$. dominated the cultured isolates. B. lentus $\mathrm{CP} 28$ generated higher urease activity and facilitated more efficient precipitation of calcium carbonate at $3.24 \pm 0.25 \times 10^{-4} \mathrm{mg} /$ cell. X-ray diffraction indicated that the dominant calcium carbonate phase was calcite. Scanning electron microscopy showed that morphologies of the minerals were dominated by cubic, rhombic and polygonal plate-like crystals. The dynamic process of microbial calcium carbonate precipitation revealed that $B$. lentus $\mathrm{CP} 28$ precipitated calcite crystals through the enzymatic hydrolysis of urea, and that when ammonium ion concentrations reached $746 \mathrm{mM}$ and the $\mathrm{pH}$ reached 9.6, that favored calcite precipitation at a higher level of $96 \mathrm{mg} / \mathrm{L}$. The results of this research provide evidence that a variety of marine bacteria can induce calcium carbonate precipitation, and may influence the marine carbonate cycle in natural environments.
\end{abstract}

Key words: calcium carbonate precipitation, calcite, marine bacteria, urease.

\section{Introduction}

Bacterial calcium carbonate precipitation is a biomineralization process, which is a common phenomenon in the bacterial kingdom (Boquet et al., 1973). It can be achieved by two different mechanisms, as either biologically-controlled or biologically-induced mineralization (Mann, 1995). In biologically-controlled mineralization, the organisms, such as magnetotatic bacteria, diatoms and coccolithophores, use specific metabolic and genetic pathways to control the process (Bazylinski and Moskowitz, 1997). However, calcium carbonate precipitation by bacteria is generally regarded as induced mineralization, as the types of minerals produced are dependent on the environmental conditions (Brennan et al., 2004). This phenomenon occurs worldwide with numerous bacterial species, in various environments, such as soils, freshwaters, oceans and saline lakes, found to participate in the precipitation of mineral carbonates (Douglas et al., 1998; Rivadeneyra et al., 1998; Peckman et al., 1999; Zamarreño et al., 2009). These bacteria play a fundamental role in the calcium biogeochemical cycle, which contributes to the formation of calcium carbonate sediments, deposits and rocks (Chafetz et al., 1991; Paerl et al., 2001).

Biologically-induced mineralization is usually carried out in open environments and the process is often linked to microbial cell surface structures and metabolic activities. Microbial extracellular polymeric substances (EPS) can trap and bind remarkable amounts of calcium to facilitate calcium carbonate precipitation, and most likely also play an essential role in calcium carbonate precipitation morphology and mineralogy (Arp et al., 1999; Braissant et al., 2007; Dupraz et al., 2005). The mineralization process associated with microbial metabolic activities usually leads to an increase in environmental alkalinity, thereby facilitating calcium carbonate precipitation (Douglas and Beveridge, 1998; Castanier et al., 1999). Among these metabolic activities, the most common is urea hydrolysis catalyzed by urease enzymes, which commonly occurs in large varieties of microorganisms (Mobley and 
Hausinger, 1989). The microbial urease enzyme hydrolyzes urea to produce carbonate and ammonia, increasing the $\mathrm{pH}$ and carbonate concentration, which then combines with environmental calcium to precipitate as calcium carbonate (Hammes et al., 2003; Muynck et al., 2010).

Calcite, aragonite and vaterite are three crystal polymorphs of calcium carbonate in bacterial systems, with calcite being the most common and stable bacterial carbonate polymorphs (Rodriguez-Navarro et al., 2012). Bacterial mineralization of aragonite, often representing the metastable polymorph, has also been reported (Pedone et al., 2010). The production of the polymorphs of calcite, aragonite and vaterite depend both on their growing environments and bacterial strains. It was reported that different bacteria precipitated different types of calcium carbonate and were mainly either spherical or polyhedral crystalline forms (Cañaveras et al., 2001). Bacterial-induced carbonate minerals have often been reported in a large number of bacteria, such as cyanobacteria (Jansson and Northen, 2010), sulphate-reducing bacteria (Warthmann et al., 2000), Bacillus (Goddette et al., 1992; Betzel et al., 1998; Jørgensen et al., 2000), Myxococcus (Rodriguez-Navarro et al., 2003; Gonzalez-Muñoz et al., 2010), Halobacteria (Sфnchez-Rom $\phi$ et al., 2011) and Pseudomonas (Jha et al., 2009). Groth et al. (2001) tested the crystal-producing ability among cave bacteria and found that all produced calcite except for Bacillus sp., which precipitated vaterites. Rodriguez-Navarro et al. (2003) reported that M. xanthus was able to induce precipitation of calcite and vaterite. Emerging evidence suggests that bacteria do not directly influence calcium carbonate morphology or polymorph selection (Chekroun et al., 2004; Bosak et al., 2005; Rodriguez-Navarro et al., 2012). The morphological features instead may be influenced by the composition of the culture medium, the specific bacterial outer structures and their chemical nature, which might be crucial for the bacterial crystallization process (Gonzalez-Muñoz et al., 2010).The aim of this study was to identify calcium carbonate producing bacteria in marine sediment and to characterize the $\mathrm{CaCO}_{3}$ crystals produced.

\section{Materials and Methods}

\section{Bacteria isolation and culture conditions}

Calcium carbonate precipitating strains were isolated from Beidaihe marine sediment $\left(119^{\circ} 31^{\prime} 18.89^{\prime \prime} \mathrm{N}\right.$ and $\left.39^{\circ} 50^{\prime} 11.90^{\prime \prime} \mathrm{E}\right)$. The sample was suspended in a filter sterilized saline solution $(0.85 \% \mathrm{NaCl})$, diluted appropriately and plated on calcium carbonate precipitation media (CCP) containing (per liter) $20 \mathrm{~g}$ of urea, $2.12 \mathrm{~g} \mathrm{NaHCO}_{3}, 10 \mathrm{~g}$ $\mathrm{NH}_{4} \mathrm{Cl}, 3 \mathrm{~g}$ of Nutrient broth, $30 \mathrm{mM} \mathrm{CaCl} 2,20 \mathrm{~g}$ agar, $\mathrm{pH}$ 8.5. The plates were then incubated at $28^{\circ} \mathrm{C}$ for 7 days, and the appearing colonies were assessed under a stereomicroscope. The positive individual colonies were finally selected based on their visual crystal formation and purified by repeated streaking on the calcium carbonate precipitation media with $\mathrm{CaCl}_{2}$ removed.

\section{DNA extract, PCR amplification and sequencing}

Bacterial genomic DNA was extracted from pure culture with the fast spin kit (Invitrogen) following the manufacturer's instructions. Amplification of 16S rRNA gene was performed in $50 \mu \mathrm{L}$ of reaction mixture containing $0.25 \mathrm{mM}$ each primer of $27 \mathrm{f}$ (5'-GTTTGATCCTG GCTCAG-3') and 1492r (5'-TACCTTGTTACGACTT3'), $0.2 \mathrm{mM}$ dNTP, $1.5 \mathrm{mM} \mathrm{MgCl}_{2}, 5 \mu \mathrm{L}$ of Taq buffer, and 5 U Taq DNA polymerase (Invitrogen, USA), 10-20 ng template DNA. PCR was then performed on a thermalcycler under the following conditions: $95{ }^{\circ} \mathrm{C}$ for $5 \mathrm{~min}, 35$ cycles of $50 \mathrm{~s}$ at $95^{\circ} \mathrm{C}, 50 \mathrm{~s}$ at $45^{\circ} \mathrm{C}$ and $1.5 \mathrm{~min}$ at $72{ }^{\circ} \mathrm{C}$, followed by a final extension for $10 \mathrm{~min}$ at $72^{\circ} \mathrm{C}$. The PCR products were visualized on an agarose gel, and the bands with the corrected size were excised and purified using the Wizard SV gel purification protocol (Promega, USA). The partial 16S rRNA fragment was sequenced on an ABI 3730 automated DNA sequencer (Applied Biosystems).

\section{Phylogenetic analysis}

Phylogenetic affiliation of each 16S rRNA sequence was initially queried by BLAST search to suggest the closest relatives against the GenBank database. The sequences were then aligned with their relatives using Clustal W, and phylogenetic trees were constructed from a matrix of pairwise genetic distances by the maximum-parsimony algorithm of the MEG 4 software. Three partial sequences of 16S rRNA genes from the strains, CP16, CP23 and CP28, isolated from Beidaihe marine sediment, have been deposited in the GenBank database under accession numbers: KF378645, KF378646, KF378647, respectively.

\section{Urease activity assay}

All the isolates were tested for their urease activity on the urea agar media containing $1.0 \mathrm{~g}$ of pancreatic digest gelatin, $1.0 \mathrm{~g}$ of dextrose, $5.0 \mathrm{~g}$ of sodium chloride, $2.0 \mathrm{~g}$ of monosodium phosphate, $20.0 \mathrm{~g}$ of urea, $12.0 \mathrm{mg}$ of phenol red, $15.0 \mathrm{~g}$ of agar, and the final $\mathrm{pH}$ was adjusted to 6.8 (Hammes et al., 2003; Chahal et al., 2011). $0.5 \mu \mathrm{L}$ cell suspension of each candidate strain $\left(10^{6} \mathrm{cells} / \mathrm{mL}\right)$ was inoculated on the urea agar media, and the plates were incubated at $28{ }^{\circ} \mathrm{C}$ for $1-2$ days. The urease activity was resolved on the media to the extent of the indication of the pink-red color, which specifically represents the generation of alkaline conditions that are attributed to the production of ammonia via urease activity on urea. An Escherichia coli strain was chosen as the negative control.

\section{Test for calcium carbonate solubilization}

Strains isolated from the calcium carbonate precipitation agar plates were tested for their solubilization capabil- 
ity of calcium carbonate on the media (CCS) containing (per liter) $0.5 \mathrm{~g}$ of yeast extract, $10 \mathrm{~g}$ of dextrose, $5 \mathrm{~g}$ of $\mathrm{CaCl}_{2}, 0.5 \mathrm{~g}$ of $\left(\mathrm{NH}_{4}\right)_{2} \mathrm{SO}_{4}, 5 \mathrm{~g}$ of $\mathrm{Ca}_{3}\left(\mathrm{PO}_{4}\right)_{2}, 0.2 \mathrm{~g}$ of $\mathrm{KCl}$, $0.1 \mathrm{~g}$ of $\mathrm{MgSO}_{4}, 0.0001 \mathrm{~g}$ of $\mathrm{MnSO}_{4}$ and $0.0001 \mathrm{~g}$ of $\mathrm{FeSO}_{4}$, $20 \mathrm{~g}$ agar, $\mathrm{pH} 7.0$, and grown at $28{ }^{\circ} \mathrm{C}$ for 5 days. The solubilization capability of calcium carbonate was quantified by measuring the diameter of the clear halo around a colony.

\section{Calcium carbonate precipitation and collection}

For calcium carbonate precipitation and collection, bacteria were grown aerobically in $100 \mathrm{~mL}$ of liquid calcium carbonate precipitation media in $500 \mathrm{~mL}$ Erlenmeyer flasks and incubated at $28{ }^{\circ} \mathrm{C}$ for $60 \mathrm{~h}$. The control consisted of uninoculated liquid calcium carbonate precipitation medium. At each time point and after the incubation, the whole culture was centrifuged at 10,000 g for $1 \mathrm{~min}$. The pellet, which included calcium carbonate precipitate and the bacteria cells, was resuspended in $50 \mathrm{~mL}$ TE buffer (10 mM Tris, $1 \mathrm{mM}$ EDTA pH 8.5). Lysozyme was added at a final concentration of $1 \mathrm{mg} / \mathrm{mL}$ and the cell suspension was incubated at $37^{\circ} \mathrm{C}$ for $1 \mathrm{~h}$ to digest the bacteria cell wall. The cell debris was removed by centrifugation and the pellet was washed with sterile distilled water ( $\mathrm{pH} 8.5)$, then air dried at $37^{\circ} \mathrm{C}$ for $24 \mathrm{~h}$. The pellet was weighed to estimate the amounts of carbonate crystals precipitated by the different strains and subjected to the following analyses.

\section{X-ray diffraction analysis (XRD)}

$\mathrm{X}$-ray diffraction (XRD) was used to determine the mineralogy of calcium carbonate precipitation induced by different bacteria. The collected dry precipitation of calcium carbonate was crushed using a mortar and pestle, then homogenized with ethanol. The powdered sample was back-packed into an aluminum sample holder and analyzed using XRD on a Panalytical X'Pert PRO MPD (Cu-K|Á) at the Nuclear Industry Geological Analysis and Testing Research Center (Beijing, China). Instrument parameters were set to $40-\mathrm{kV}$ accelerating voltage and $35-\mathrm{mA}$ current. Scans were run from $20^{\circ}$ to $60^{\circ} 2 \theta$ at a scanning speed of $0.01 \%$. The peak in the $\mathrm{d}(112)$ was used to determine the calcite minerals.

\section{Scanning electron microscopy (SEM)}

Morphology of calcium carbonate precipitation was observed by scanning electron microscopy (SEM Hitachi $\mathrm{S}-450)$. The collected carbonate crystals were mounted directly into the SEM stubs and sputter-coated with a gold/palladium mixture (Hitachi HUS-5GB coating unit). Scanning was performed under the condition of accelerating voltage at $25 \mathrm{kV}$.

\section{Cell number, $\mathrm{pH}$ and chemical analytic methods}

In order to determine the correlation of calcium carbonate formation to the parametric changes during the growth phase of $B$. lentus $\mathrm{CP} 28$, parameters such as cell number, $\mathrm{pH}$ and ammonia were monitored at constant time intervals. At each time point of post incubation, a $0.5 \mathrm{~mL}$ aliquot of the culture was taken from the flask, appropriately diluted, then spread on the nutrition broth agar (per liter, $5 \mathrm{~g}$ of enzymatic digest gelatin, $3 \mathrm{~g}$ of beef extract, $15 \mathrm{~g}$ of agar) and incubated at $28{ }^{\circ} \mathrm{C}$ for $24 \mathrm{~h}$ to determine the cell numbers. Calcium carbonate precipitation was determined as described above and the supernatant was used to determine the $\mathrm{pH}$ and the concentration of ammonia. $\mathrm{pH}$ was measured using a $\mathrm{pH}$ indicator (PB-10, Sartorius AG). Ammonia released in the medium as a result of urea hydrolysis was determined by the spectrophotometric method (Natarajan et al., 1995).

\section{Results}

\section{Isolation of bacteria involved in inducing calcium carbonate precipitation}

Twenty strains were isolated from calcium carbonate precipitation agar plates, all of which could induce the precipitation of calcium carbonate under those conditions. Microscopy revealed that precipitation started with a scattered white spot circling the bacteria colony, then developed into a hard gray-white crystal covering the colony with an encircling scattered white spot appearing after 7 days. Based on the morphological differences of crystal formed on the agar plate, the strains were divided into two types, those demonstrating either strong induction or weak induction of calcium carbonate. Five and fifteen colonies, belonging to the two types respectively, were isolated and selected for the further studies.

\section{Phylogenetic analysis of the isolated candidate strains}

A total of twenty isolates were identified and characterized by sequencing of $16 \mathrm{~S}$ rDNA. These sequences were BLAST searched against the GenBank database using the BLASTN program. Twenty isolates belonging to three genera were identified, and had the closest relatives belonging to Sporosarcina sp., Bacillus sp. and Brevundimonas sp. (Figure 1). Sequences related to Sporosarcina sp. (occupied $75 \%$ of total sequences based on $98 \%$ of sequence similarity) dominated the cultured isolates, which included 15 isolates (CP1, CP3 to CP10, CP13, CP14, CP18 to CP20, CP23), followed by Bacillus sp. (occupied $20 \%$ of total sequences based on $98 \%$ of sequence similarity), which included 4 isolates (CP28 to CP31) and Brevundimonas sp. (occupied $5 \%$ of total sequences based on $99 \%$ of sequence similarity) which was comprised of a single isolate (CP16).

\section{Characterization of three phylogenetic distinct strains}

$\mathrm{CP} 16, \mathrm{CP} 23$ and CP28, closely related to $B$. diminuta, $S$. soli and $B$. lentus, were investigated and characterized by 


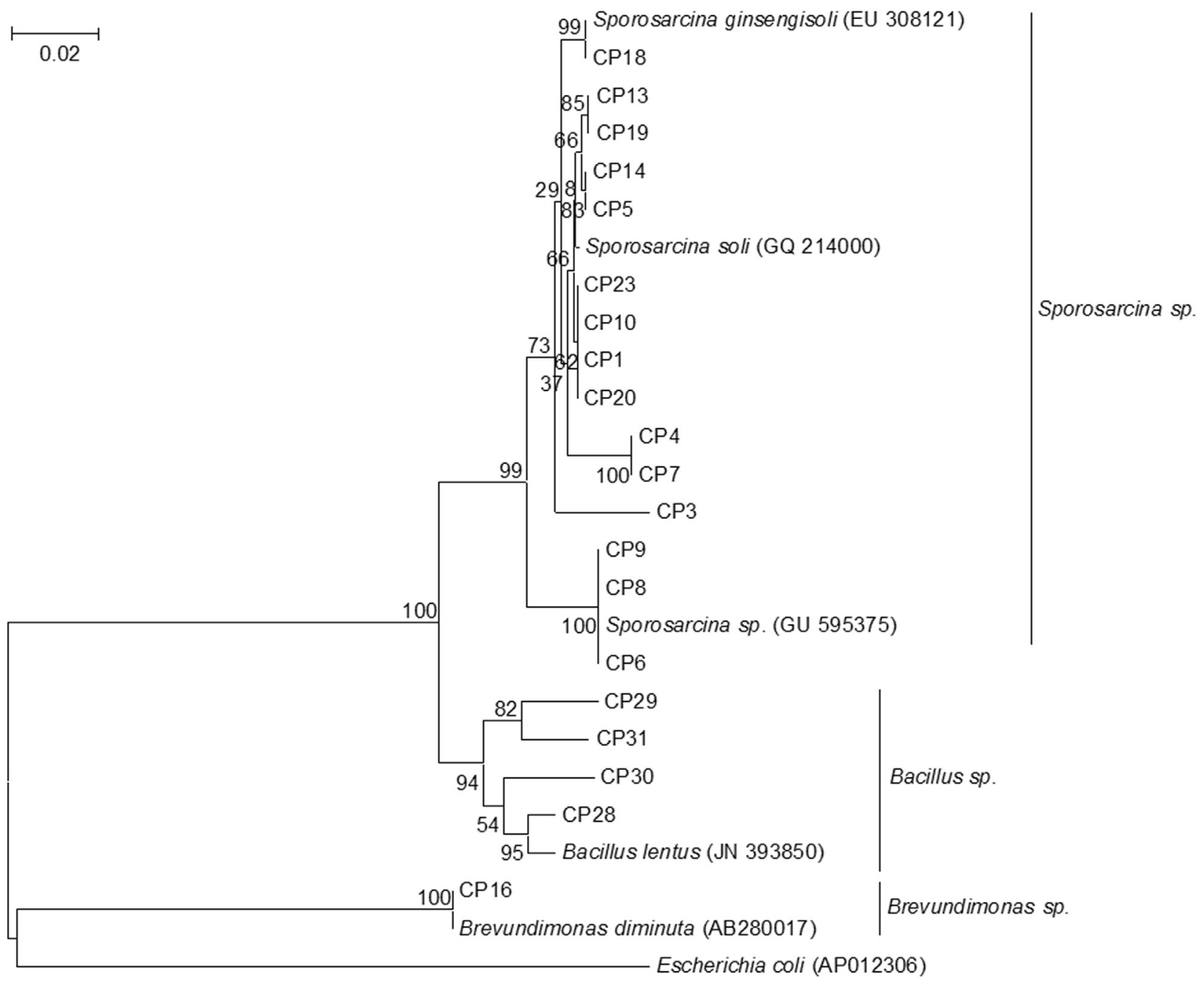

Figure 1 - Neighbor-joining tree based on partial 16S rRNA gene sequences showing the phylogenetic relationship of the 20 isolates and their closest relatives. The phylogenetic tree was generated using approximately $1,400 \mathrm{bp}$ of $16 \mathrm{~S}$ rRNA sequence by the neighbor-joining method. Reference strains used in the tree can be retrieved with their accession numbers in GenBank. Scale bar equals approximately $2 \%$ nucleotide divergence.

their growth rate, capability of inducing calcium carbonate precipitation, urease activity, and calcium carbonate solubilization ability. B. lentus CP28 grew faster and faciliated more calcium carbonate precipitation than the strains of $B$. diminuta $\mathrm{CP} 16$ and $S$. soli $\mathrm{CP} 23$ (Figure 2). After $60 \mathrm{~h}$ of incubation, the cell number of CP16, CP23 and CP 28 were $2.78 \pm 0.38 \times 10^{6}, 2.38 \pm 0.28 \times 10^{6}$ and $2.87 \pm 0.42 \times 10^{6}$ cells $/ \mathrm{mL}$, respectively. The masses of the precipitates of the three strains were $842 \pm 80,456 \pm 70$ and $931 \pm 98 \mathrm{mg} / \mathrm{L}$, respectively. CP28 was the most efficient strain at inducing calcium carbonate precipitation when calculations were based on the mass of precipitation per cell, with CP28 capable of inducing calcium carbonate precipitation at $3.24 \pm$ $0.25 \times 10^{-4} \mathrm{mg} / \mathrm{cell}$.

Microbial-induced calcium carbonate precipitation by urea hydrolysis was investigated extensively. The bacterium converts urea into ammonia by producing the enzyme urease, thus increasing the environmental $\mathrm{pH}$ and subsequently inducing calcium carbonate precipitation. All 20 of the isolated strains possessed the urease activity when tested in the urea agar media. Among of tested strains, CP23 and CP28 generated higher urease activity than CP16, whereas the E. coli strain did not show any purple color surrounding the inoculated site, which indicates a lack of urease activity. This urease activity assay result, together with the result in Figure 2, implied that the mass of calcium carbonate precipitation was directly linked to the urease activity, with higher urease activity causing more calcium carbonate precipitation. Therefore, strains CP16, CP23 and CP28 were chosen for further analyses.

CP16, CP23 and CP28 were dot inoculated on the calcium carbonate precipitation media and incubated for 7 days in order to compare the diameter of the crystal halo surrounding the inoculation site. Table 1 shows that diameter of the crystal ring formed by CP2 8 was larger than that 
of CP23. However, no calcium carbonate formed when plates were inoculated with $E$. coli control. To determine whether the isolates play roles in the deterioration of lime-

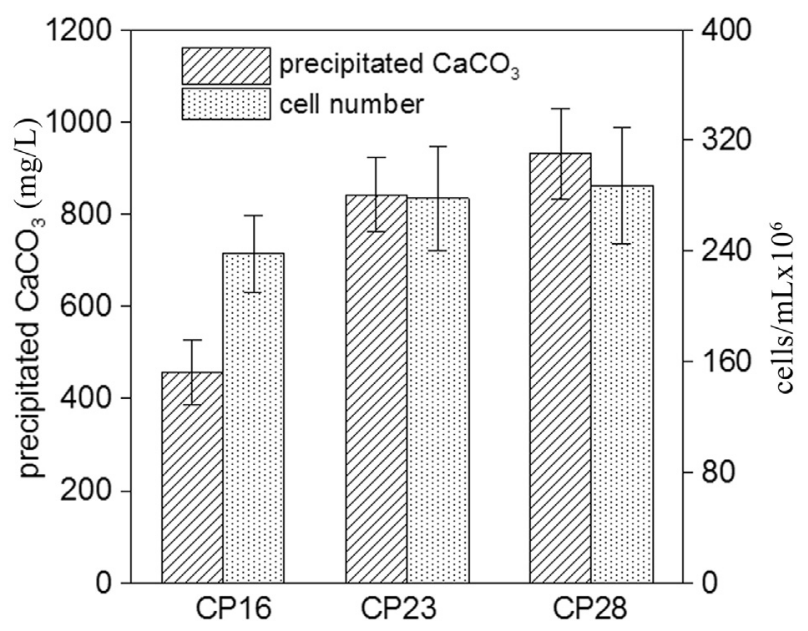

Figure 2 - Comparison of the growth rate and capability of inducing calcium carbonate precipitation among the strains of $B$. diminuta CP16, $S$. soli $\mathrm{CP} 23$ and B. lentus $\mathrm{CP} 28$.

Table 1 - Characterization of the isolates on precipitation and dissolution of $\mathrm{CaCO}_{3}$.

\begin{tabular}{lcc}
\hline Strains & $\begin{array}{c}\mathrm{CaCO}_{3} \text { precipitation on } \\
\text { CCP media }\end{array}$ & $\begin{array}{c}\mathrm{CaCO}_{3} \text { dissolution on } \\
\mathrm{CCS} \text { media }\end{array}$ \\
\hline E. coli $\mathrm{CK}$ & $-{ }^{\mathrm{a}}$ & $-^{\mathrm{a}}$ \\
B. diminuta $\mathrm{CP} 16$ & + & $-^{\mathrm{a}}$ \\
S. soli $\mathrm{CP} 23$ & +++ & + \\
B. lentus $\mathrm{CP} 28$ & ++++ & $-^{\mathrm{a}}$ \\
\hline
\end{tabular}

Notes: + and ${ }^{-}$indicate the relative degree of precipitation or dissolution of $\mathrm{CaCO}_{3}$ among $E$. coli and the tested ureolytic bacteria. stone by solubilizing calcium carbonate, carbonate-solubilization capability was tested on the calcium carbonate solubilization media. Both CP16 and CP23 dissolved calcium carbonate and formed a clear, circular halo around the inoculation site. However, CP28 did not form similar halos. These data suggested that the mechanism of calcium carbonate precipitation induced by bacteria may change with variations in environmental conditions.

\section{SEM and XRD analyses of microbically-induced calcium carbonate precipitation}

Precipitations collected on the 7th day were analyzed by XRD. The results showed that all three strains, $B$. diminuta $\mathrm{CP} 16, S$. soli $\mathrm{CP} 23$, B. lentus $\mathrm{CP} 28$, induced the formation of calcite (Figure 3), which was the only crystal assayed in the XRD spectra.

Morphologies of crystals induced by CP16, CP23 and CP28 were observed under SEM microscopy, and the results showed the morphologies of crystals induced by CP16, CP23 and CP28 were similar. Basically, five different morphologies of crystals, the cubic crystal, the rhombic crystal, the polygonal plate-like crystal, the spherical crystal, and the irregular shaped crystal, were observed (Figure 4). The cubic, the rhombic and the polygonal plate-like crystal were the three main shapes of crystals induced by the isolates, while the spherical and the irregular shaped crystals were less common (Figure 4A). Different morphologies of crystal showed the different properties of aggregated minerals described as follows. The surfaces of cubic shaped crystals were smooth (Figure 4B). The rhombicshaped (Figure 4C and 4D) and the polygonal plate-like (Figure $4 \mathrm{E}$ and $4 \mathrm{~F}$ ) crystals generally presented welldefined faces and edges with accumulation of plate-like structures. The spherical crystals were formed by accumulation of granular composition with a rough surface (Figu-

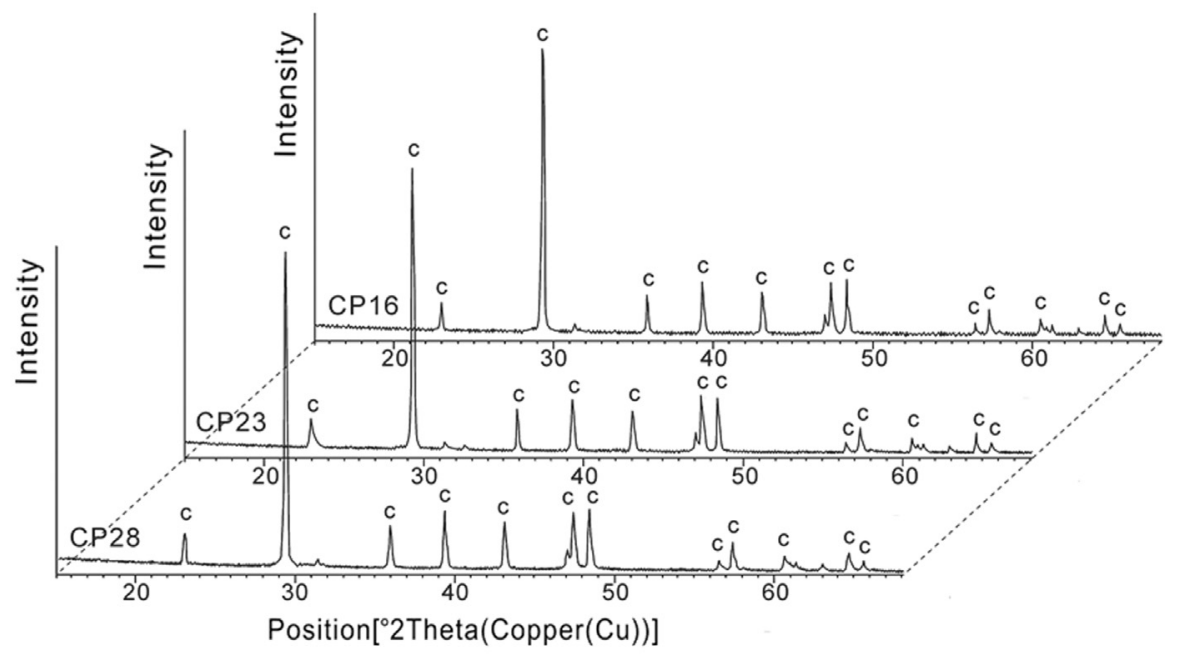

Figure 3 - XRD spectra of the calcium carbonate crystals induced by bacteria. C, calcite. From top to bottom: B. diminuta CP16, S. soli CP23 and B. lentus CP28. 


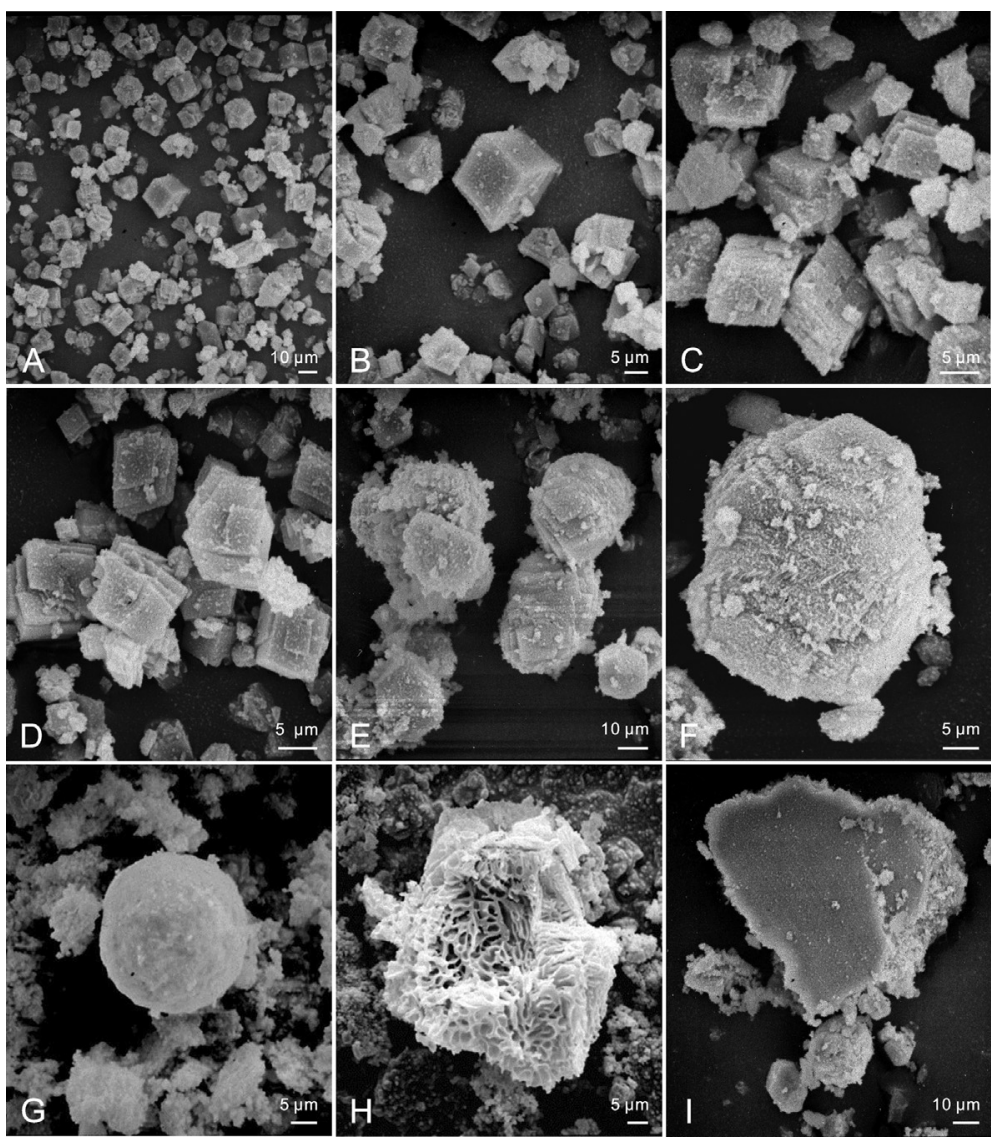

Figure 4 - SEM micrographs revealing the different morphologies of calcite crystals induced by B. lentus CP28. A) morphologies of crystals; B) the cubic crystal; Cand D) the rhombic crystal; E and F) the polygonal plate-like caystal; G) the spherical crystal; H and I) the irregular crystal.

re 4G). The irregular porous shaped crystals appeared to be amorphous with many tiny holes inside (Figure 4H). Another kind of irregular crystals with smoothed surfaces were also occasionally observed (Figure 4I).

\section{Chemical process of calcium carbonate precipitation induced by $B$. lentus CP28}

Based on our observation and analyses, all the strains induced calcite precipitation in the liquid media. To determine the correlation of calcium carbonate formation with the metabolic parameter changes on the growth phase of $B$. lentus CP28, several parameters, including $\mathrm{pH}$, cell number, ammonium ion concentration and mass of calcium carbonate, were monitored. The amount of calcium carbonate precipitation appeared to maintain a positive correlation with the growth of $B$. lentus $\mathrm{CP} 28$ (Figure 5). The $\mathrm{pH}$ quickly increased from the initial $\mathrm{pH}$ of 8.3 to 9.4 in the first $12 \mathrm{~h}$ of inoculation. While in the stage of log phase growth, $B$. lentus CP28 maintained robust growth, and the concentration of ammonium ions, which is believed to have contributed to the rise of $\mathrm{pH}$, increased to $608 \mathrm{mM}$. Relatively more calcium carbonate precipitation was precipitated during this period. When the growth of B. lentus $\mathrm{CP} 28$ was in the stationary phase after $12 \mathrm{~h}$ of incubation, the $\mathrm{pH}$ gradu- ally increased to 9.6 from 9.4 and the ammonium ion concentration slightly increased to $746 \mathrm{mM}$. During this period, the rate of calcium carbonate precipitation was lower than that of the first phase. The calcium carbonate precipitation tended to reach plateaus, with a production of $96 \mathrm{mg} / \mathrm{L}$ in this phase. However, in the control experiment without bacteria, the $\mathrm{pH}$ of the media increased only slightly from 8.3 to 8.4 , and the concentration of ammonium ions remained relatively stable. With such slight alkalinity of the media, only trace calcium carbonate precipitation was collected in the control experiments (Figure 5).

\section{Discussion}

Previous studies demonstrated that a great diversity of microbial genera took part in calcium carbonate precipitation in various natural environments (Wright and Oren, 2005), such as soils, freshwater, oceans and saline lakes (Douglas et al., 1998; Rivadeneyra et al., 1998; Peckman et al., 1999; Zamarreño et al., 2009). Our research showed that a variety of bacteria inhabiting the marine sediments could also induce calcium carbonate precipitation. Three genera of bacteria, Sporosarcina, Bacillus and Brevundimonas, were identified as precipitating calcium carbonate. S. soli, rather than $B$. lentus and B. diminuta, was 


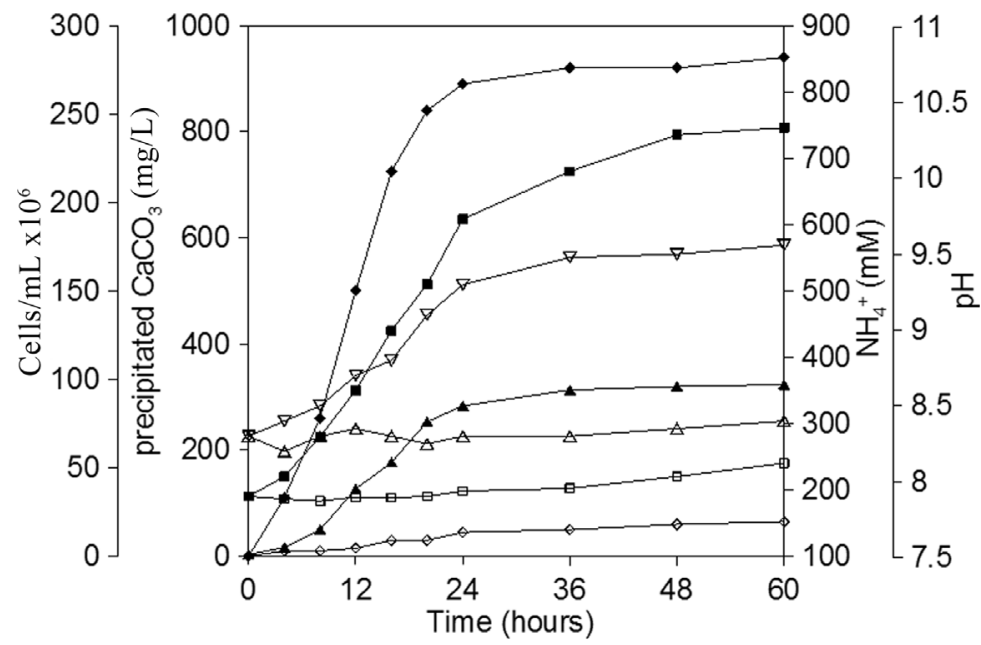

- precipitated $\mathrm{CaCO}_{3}$ with bacteria; $\diamond$, precipitated $\mathrm{CaCO}_{3}$ without bacteria; $\boldsymbol{\sim} \mathrm{NH}_{4}^{+}$with bacteria; $\square, \mathrm{NH}_{4}{ }^{+}$without bacteria; $\boldsymbol{\Delta}$, cell number; $\Delta$, $\mathrm{pH}$ without bacteria; $\nabla, \mathrm{pH}$ with bacteria.

Figure 5 - Dynamic analysis of calcium carbonate precipitation induced by B. lentus CP28 associated with changes of pH, ammonium ion, cell growth. Data reflect average of three experiments performed in triplicate.

found to be the dominant cultured species. In previous studies, Sporosarcina pasteurii (formerly known as Bacillus pasteurii from older taxonomies) and Bacillus subtilis were frequently reported to be isolated from various environments and studied for calcium carbonate biomineralization or for being a limestone consolidant (Stocks-Fischer et al., 1999; Fujita et al., 2000; Bachmeier et al., 2002; Achal et al., 2009; Zamarreño et al., 2009; Okwadha and Li, 2010). $B$. diminuta was found to be the most effective carbonatogenic bacterium isolated from decayed building stones (Jroundi et al., 2010; Rodriguez-Navarro et al., 2012), while $B$. lentus from soil, marine waters and sediments was often used as a producer of alkaline protease in industry (Goddette et al., 1992; Betzel et al., 1988; Jørgensen et al., 2000). Biomineralization of calcium carbonate facilited by $B$. lentus was also reported. Our data showed that the bacterium could strongly induce calcium carbonate precipitation in comparison to the other strains in our experiments. With considerable researches, broad ranges of bacteria were found to be involved in the process of calcium carbonate biomineralization. It is thought that calcium carbonate biomineralization is not necessarily linked to any particular group of organisms but rather a general phenomenon in the bacterial world (Boquet et al., 1973; Ehrlich, 1998).

Considerable research on carbonate precipitation by bacteria has been performed using ureolytic bacteria (Hammes et al., 2003; Ai-Thawadi, 2011), which by means of urea hydrolysis produce ammonia and carbonate ion, leading to an increase in $\mathrm{pH}$, and thus favoring calcium carbonate precipitation. Our data showed that urease activity was present in all the isolates when tested on the urease activity assay media. The strain of $B$. lentus CP28 exhibited higher urease activity and more rapid growth and crystallization of calcium carbonate aggregation than strains $B$. diminuta $\mathrm{CP} 16$ and $S$. soli $\mathrm{CP} 23$. This observation coincides with the observations by Hammes et al. (2003), who reported a diversity of urease genes in the genomes of ureolytic bacteria and proposed that their high affinities and specific rates were the basase of rapid crystal formation. Urea is an organic nitrogenous compound present in coastal environments and introduced by the excretion of certain terrestrial and aquatic animals. Biotic urease activity is widespread in the environment and includes the actions of bacteria, yeasts and filamentous fungi (Mobley and Hausinger, 1989). Urease hydrolyses the substrate urea, which creates an alkaline environment to facilitate calcium carbonate precipitation in the natural settings, and thus partially contributes to the marine lithifications. With removal of urea from the experimental media, strains $B$. diminuta $\mathrm{CP} 16$ and $S$. soli CP23 were switched to metabolizing glucose and probably produced organic acids to dissolve calcium carbonate (Table 1). This phenomenon was observed in cave isolates, demonstrating their abilities to precipitate and dissolve calcium carbonate (Banks et al., 2010). Therefore, we inferred that the processes of both precipitation and dissolution of calcium carbonate are dynamic processes in the natural marine sediment system, with both processes depending on the availability of urea and other organic substances.

Calcite, aragonite and vaterite are three crystalline polymorphs of calcium carbonate existing in natural environments. Calcite and vaterite are the most common crystalline polymorphs induced by ureolytic bacteria (Boquet et al., 1973; Rivadeneyra et al., 1996; Stocks-Fisher et al., 1999; Bang et al., 2001; Giralt et al., 2001; Bachemeier et al., 2002; Kawaguchi and Decho, 2002;). It has been reported that aragonite could also be precipitated by bacteria 
(Rivadeneyra et al., 1996). Zamarreño et al. (2009) demonstrated that Pseudomonas D2 and F2 have a remarkable ability to induce the precipitation of primarily calcite and vaterite, similar to the results obtained by RodriguezNavarro et al. (2003) and Muynck et al. (2008), who used Myxococcus xanthus and Bacillus sphaericus in their work, respectively. Acinetobacter B14 induced more precipitation of vaterite than calcite (Zamarreño et al., 2009), Deleya halophlia induced precipitation of aragonite (Rivadeneyra et al., 1996), whereas Lysinibacillus sphaericus INQCS 414 precipitated only vaterite (Shirakawa et al., 2011). In contrast, our research isolates of $B$. diminuta CP16, S. soli CP23 and B. lentus CP28 predominantly induced calcite precipitation. Nevertheless, this finding is consistent with the results from Li et al. (2011) and Achal et al. (2009), who reported using Bacillus sp. and S. pasteurii MTCC 1761, respectively, to induce calcium carbonate precipitation. Despite extensive studies on bacterial carbonatogenesis, little is known about what causes bacteria to precipitate different carbonate polymorphs. Besides the observation that the particular bacterial species used has an important influence on the type of carbonate precipitation, the composition of the culture medium is also believed to be one of the determinants (Rivadeneyra et al., 1996, 1998; Gonzalez-Munoz et al., 2010;). It has also been reported that the specific amino acid sequence in the urease enzyme of bacteria may be responsible for the carbonate polymorph selection. Higher concentration of Asp and Glu in the urease of $B$. pasteurii favored the formation of vaterite, while calcite was the predominant precipitate when using urease of Canavalia ensiformis with a lower concentration of Asp and Glu (Sondi and Salopek-Sondi, 2005). Kawaguchi and Decho (2002) reported that specific proteins in extracellular polymeric substances (EPS) of Schizothrix sp. influenced aragonite and calcite polymorph selection. These previous studies suggest that the polymorph selection is a complex process involving a variety of abiotic and biotic factors.

Our results showed that $B$. diminuta $\mathrm{CP} 16, S$. soli CP23 and B. lentus CP28 induced similar morphologies of crystals. The cubic, rhombic and polygonal plate-like crystals were the dominant crystals compared with the less common spherical and irregularly shaped crystals. This result is consistent with that Tourney and Ngwenya (2009) observed from a strain of Bacillus licheniformis S-86. According to Li et al. (2010), the crystal morphologies of precipitates produced by Bacillus sp. mainly showed cubic and polyhedral shapes. Zamarreño et al. (2009) reported that microbial calcite crystals presented a variety of morphologies depending on the type of isolate. Pseudomonas putida F2 induced nailhead and spheroidal crystals, Pseudomonas aeruginosa D2 induced pseudo-ellipsoidal and pseudo-cubic crystals, whereas Acinetobacter junii B14 induced semi-spheroidal, pseudo-hexagonal prism and nailhead spar crystals in the same growth medium.
The process of calcium carbonate precipitation is usually governed by four key factors: (1) calcium concentration, (2) concentration of dissolved inorganic carbon, (3) $\mathrm{pH},(4)$ the availability of nucleation sites (Muynck et al., 2010). The first three factors can be influenced by bacteria, most notably, the creation of an alkaline environment. Moreover, the bacteria can also provide the crystal nucleation sites for calcium carbonate precipitation (Hammes and Verstraete, 2002). In the process of calcium carbonate precipitation, bacterial precipitation caused faster precipitation rates than chemical precipitation (Stocks-Fischer et al., 1999). As shown in Figure 5, calcium carbonate precipitation was clearly correlated with the growth of $B$. lentus CP28, which utilized ureases to hydrolyze urea and generate carbonate and ammonia, and result in an increase in $\mathrm{pH}$. With the rise of $\mathrm{pH}$, more ammonium ion was released and a considerable quantity of calcium carbonate was precipitated. On the other hand, it is also possible that with the bacterial cell number increase more crystal nucleation sites were available, favoring the calcium carbonate precipitation (Stocks-Fisher et al., 1999). In the bacterium-free control, both $\mathrm{pH}$ and ammonium ion concentration kept increasing slightly while little calcium carbonate precipitation was collected. The kinetics of microbial calcium carbonate precipitation are similar to those of reported by Stocks-Fisher et al. (1999). The data obtained from the bacterial process of calcium carbonate precipitation induced by B. lentus $\mathrm{CP} 28$ provides straightforward evidence to understand microbial calcium carbonate precipitation.

In summary, in this paper we have clearly shown that three species of bacteria isolated from marine sediment participate in microbial calcium carbonate precipitation through hydrolysis of urea. Mineralogical analysis of the induced calcium carbonate precipitation shows that calcite is the dominant carbonate polymorph, and morphologies of crystals are mainly cubic and rhombic. These results suggest that production of carbonate polymorph is not specifically related to any bacterial species, but is rather influenced by complicated environmental factors such as the $\mathrm{pH}$, the composition of the media, etc.

\section{Acknowledgments}

The authors acknowledge James Hurley of Department of Plant Pathology and Microbiology, Texas A \& M University, for making a critical reading and revision of this paper. This research were supported by the Fundamental Research Funds for the Central Universities (2652012138) and National Natural Science Foundation of China (41030853).

\section{References}

Achal V, Mukherjee A, Basu PC et al. (2009) Strain improvement of Sporosarcina pasteurii for enhanced urease and calcite production. J Industrial Microbiol Biotechnol 36:981-988. 
Ai-Thawadi SM (2011) Ureolytic bacteria and calcium carbonate formation as a mechanism of strength enhancement of sand. J Adv Sci Eng Res 1:98-114.

Arp G, Thiel V, Reimer A et al. (1999) Biofilm exopolymers control microbialite formation at thermal spring discharging into the alkaline Pyramid Lake, Nevada, USA. Sediment Geol 126:159-176.

Bachmeier KL, Williams AE, Warmington JR et al. (2002) Urease activity in microbiologically-induced calcite precipitation. J Biochechnol 93:171-181.

Bang SS, Galimat JK, Ramakrishan V (2001) Calcite precipitation induced by polyurethane-immobilized Bacillus pasteurii. Enzyme Microb Technol 28:404-409.

Banks ED, Taylor NM, Gulley J et al. (2010) Bacterial calcium carbonate precipitation in cave environments: A function of calcium homeostasis. Geomicrobiology J 27:444-454.

Bazylinski DA, Moskowitz BM (1997) Microbial biomineralization of magnetic iron minerals: microbiology, magnetism and environment significance. Rev Mineral Geochem 35:181-223.

Betzel C, Dauter Z, Dauter M et al. (1988) Crystallization and preliminary X-ray diffraction studies of an alkaline protease from Bacillus lentus. J Mol Biol 204:803-804.

Boquet E, Boronat A, Ramos-Cormenzana A (1973) Production of calcite (calcium carbonate) crystals by soil bacteria is a general phenomenon. Nature 246:527-529.

Bosak T, Newman DK (2005) Microbial kinetic controls on calcite morphology in supersaturated solutions. J Sediment Res 75:190-199.

Braissant O, Decho AW, Dupraz C et al. (2007) Exopolymeric substance of sulfate-reducing bacteria: interactions with calcium at alkaline $\mathrm{pH}$ and implication for formation of carbonate minerals. Geobiology 5:401-411.

Brennan ST, Lowenstein TK, Horita J (2004) Seawater chemistry and the advent of biocalcification. Geology 32:473-476.

Cañaveras JC, Sacchez-Moral S, Soler V et al. (2001) Microorganisms and microbially induced fabrics cave walls. Geomicrobiology J 18:223-240.

Castanier S, Le M|tayer-Levrel G, Perthuisot JP (1999) Carbonate precipitation and limestone genesis-the microbiologist point of view. Sedimentary Geol 126:9-23.

Castanier S, Le M|tayer-Levrel G, Perthuisot JP (2000) Bacterial roles in the precipitation of carbonate minerals. In: Microbial sediments. Springer, Heidelberg, Germany. pp 32-39.

Chafetz HS, Rush P, Utech NM (1991) Microenvironmental controls on mineralogy and habitat of $\mathrm{CaCO}_{3}$ precipitates: an example from an active travertine system. Sedimentology 38:107-126.

Chahal N, Rajor A, Siddique R (2011) Calcium carbonate precipitation by different bacterial strains. Afr J Biotechnol 10:8359-8372.

Chekroun KB, Rodríguez-Navarro C, Gonzalez-Muñoz MT et al. (2004) Precipitation and growth morphology of calcium carbonate induced by Myxococcus xanthus: implication for recognition of bacterial carbonates. J Sediment Res 74:868876.

Douglas S, Beveridge TJ (1998) Mineral formation by bacteria in natural microbial communities. FEMS Microbiol Ecol 26:79-88.
Dupraz C, Visscher PT (2005) Microbial lithification in marine stromatolites and hypersaline mats. Trends Microbiol 13:429-438.

Fujita Y, Ferris EG, Lawson RD et al. (2000) Calcium carbonate precipitation by ureolytic subsurface bacteria. Geomicrobiol J 17:305-318.

Giralt S, Julia R, Klerkx JJ (2001) Microbial biscuits of vaterite in Lake Issyk-Kul (Republic of Kyrgyzstan). J Sediment Res 71:430-435.

Goddette DW, Paech C, Yang SS et al. (1992) The crystal structure of the Bacillus lentus alkaline protease, subtilisin BL, at 1.4 A resolution. J Mol Biol 228:580-595.

Gonzalez-Muñoz MT, Rodriguez-Navarro C, Martinez-Ruiz F et al. (2010) Bacterial biomineralization: new insights from Myxococcus-induced mineral precipitation. Geological Society, London Special Publications 336:31-50.

Groth I, Schumann P, Laiz I et al. (2001) Geomicrobiological study of the Grotta dei Cervi, Porto Badisco, Italy. Geomicrobiol J 18:241-258.

Hammes F, Verstraete W (2002) Key roles of pH and calcium metabolism in microbial carbonate precipitation. Rev Environ Sci Biotechnol 1:3-7.

Hammes F, Boon N, Villiers JD et al. (2003) Strain-specific ureolytic microbial calcium carbonate precipitation. Appl Environ Microbiol 69:4901-4909.

Jansson C, Northen T (2010) Calcifying cyanobacteria-the potential of biomineralization for carbon capture and storage. Curr Opin Biotechnol 21:1-7.

Jha BK, Pragash MG, Cletus J et al. (2009) Simultaneous phosphate solubilization potential and antifungal activity of new fluorescent pseudomonad strains, Pseudomonas aeruginosa, P. plecoglossicida and P. mosselii. World J Microbiol Biotechnol 25:573-581.

Jroundi F, Fernфndez-Vivas A, Rodriguez-Navarro C et al. (2010) Bioconservation of deteriorated monumental calcarenite stone and identification of bacteria with carbonatogenic activity. Environ Microbiol 60:39-54.

Jørgensen PL, Tangney M, Pedersen PE et al. (2000) Cloning and sequencing of an alkaline protease gene from Bacillus lentus and amplication of the gene on the B. lentus chromosome by improved technique. Appl Environ Microbiol 66:825-827.

Kawaguchi T, Decho AW (2002) A laboratory investigation of cyanobacterial extracellular polymeric secretions (EPS) in influencing $\mathrm{CaCO}_{3}$ polymorphism. J Cryst Growth 240:230-235.

Li W, Liu L, Chen W et al. (2010) Calcium carbonate precipitation and crystal morphology induced by microbial carbonic anhydrase and other biological factors. Process Biochem 45:1017-1021.

Li W, Liu LP, Zhou PP et al. (2011) Calcite precipitation induced by bacteria and bacterially produced carbonic anhydrase. Curr Sci 100:502-508.

Mann S (1995) Biomineralization and biomimetic materials chemistry. J Mater Chem 5:935-946.

Mobley HL, Hausinger RP (1989) Microbial ureases: significance, regulation, and molecular characterization. Microbiol Mol Biol Rev 53:85-108.

Muynck WD, Cox K, Belie ND et al. (2008) Bacterial carbonate precipitation as an alternative surface treatment for concrete. Constr Build Mater 22:875-885 
Muynck WD, Belie ND, Verstraete W (2010) Microbial carbonate precipitation in construction materials: A review. Ecol Eng 36:118-136.

Natarajan KR (1995) Kinetic study of the enzyme urease from Dolichos biflorus. J Chem Educ 72:556-557.

Okwahha GDO, Li J (2010) Optimum conditions for microbial carbonate precipitation. Chemosphere 81:1143-1148.

Paerl HW, Steppe TF, Reid RP (2001) Bacterially mediated precipitation in marine stromatolites. Environ Microbiol 3:123-130.

Peckman J, Paul J, Thiel V (1999) Bacterially mediated formation of diagenetic aragonite and native sulphur in Zechstein carbonate (Upper Permian, central Germany). Sediment Geol 126:205-222.

Pedone VA, Folk RL (2010) Formation of aragonite cement by nannobacteria in the Great Salt Lake, Utah. Geology 24:763-765.

Rivadeneyra MA, Ramoss-Cormenzana A, Delgado G et al. (1996) Process of carbonate precipitation by Deleya halophila. Curr Microbiol 36:308-313.

Rivadeneyra MA, Delgado G, Ramos-Cormenzana A et al. (1998) Biomineralization of carbonates by Halomonas eurihalina in solid and liquid media with different salinities: crystal formation sequence. Res Microbiol 149:277-287.

Rodriguez-Navarro C, Jroundi F, Schiro M et al. (2012) Influence of substrate mineralogy on bacterial mineralization of calcium carbonate: implication for stone conservation. Appl Environ Microbiol 78:4017-4029.

Rodriguez-Navarro C, Rodriguez-Gallego M, Chekroun KB et al. (2003) Conservation of ornamental stone by Myxococcus xanthus-induced carbonate biomineralization. Appl Environ Microbiol 69:2182-2193.

Sønchez-Romøn M, Romanek CS, Fernøadez-Remolar DC et al. (2011) Aerobic biomineralization of Mg-rich carbonates: Implications for natural environments. Chem Geol 281:143-150.

Shirakawa MA, Cincotto MA, Atencio D et al. (2011) Effect of culture medium on biocalcification by Pseudomonas putida, Lysibacillus sphaericus and Bacillus subtilis. Braz J Microbiol 42:499-507.

Sondi I, Salopek-Sondi B (2005) Influence of the primary structure of enzymes on the formation of $\mathrm{CaCO}_{3}$ polymorphs: a comparison of plant (Canavalia ensiformis) and Bacterial (Bacillus pasteurii) urease. Langmuir 21:8876-8882.

Stocks-Fischer S, Galinat JK, Bang SS (1999) Microbiological precipitation of $\mathrm{CaCO}_{3}$. Soil Biol Biochem 31:1563-1571.

Tourney T, Ngwenya BT (2009) Bacteria extracellular polymeric substance (EPS) mediate $\mathrm{CaCO}_{3}$ morphology and polymorphism. Chem Geol 262:138-146.

Warthmann R, Van Lith Y, Vasconcelos C et al. (2000) Bacterially induced dolomite precipitation in anoxic culture experiments. Geology 28:1091-1094.

Wright DT, Oren A (2005) Nonphotosynthetic bacteria and the formation of carbonates and evaporates through time. Geomicrobiol J 22:27-53.

Zamarreño DV, Inkpen R, May E (2009) Carbonate crystals precipitated by freshwater bacteria and their use as a limestone consolidant. App Environ Microbiol 75:5981-5990.

Associate Editor: Valeria Maia de Oliveira

All the content of the journal, except where otherwise noted, is licensed under a Creative Commons License CC BY-NC. 